\title{
PEMANFAATAN GULA AREN ORIGINAL (AREO) SEBAGAI BAHAN OLAHAN PRODUK KULINER LOKAL DALAM PENGEMBANGAN KEWIRAUSAHAAN MASYARAKAT DESA KEKAIT KABUPATEN LOMBOK BARAT
}

\author{
Oleh \\ I Putu Gede ${ }^{1)}$ \& I Ketut Purwata ${ }^{2)}$ \\ ${ }^{1,2}$ Sekolah Tinggi Pariwisata Mataram \\ Email: 1iputugede@gmail.com \& $\underline{\text { 2iketutpurwata@gmail.com }}$
}

\begin{abstract}
The need for and dependency on national sugar consumption, especially sugar, has increased from year to year. The diversification program of the national sugar industry can be carried out by finding alternative sources of natural sources of sugar cane, one of which is sugar from palm sugar. The development of the palm sugar home industry as a supporting component of the tourism service business in West Lombok Regency cannot be ignored. the high diversity of deviations in the quality standard of the product produced becomes the problem of palm sugar in meeting production standards. the purpose of this service is to describe the diversity of the quality of palm sugar in the production process from the results of the crafters, with the method used in stages through the method of socialization in practice with direct observation techniques. With the results there was a significant increase in standard production capacity, namely 2 times in the morning and evening with a total production of 15-20 kg per group, with production patterns and an increase in enabling good product marketing with the target market not only local consumers but also more consumers spacious and modern.
\end{abstract}

Keywords : Palm Sugar, Local Culinary, Entrepreneurship

\section{PENDAHUALUAN}

Gula merupakan salah satu komoditi penting dan strategis bagi masyarakat. Tidak hanya konsumen sebagai pengguna akhir yang merasakan pentingnya ketersediaan gula, namun juga bagi kalangan industri sebagai produsen yang memanfaatkan komoditi gula sebagai bahan baku menjadi produk dengan added value yang lebih tinggi (KPPU 2010). Kebutuhan dan ketergantungan konsumsi gula nasional khususnya terhadap gula pasir semakin meningkat dari tahun ke tahun. Selama ini kebutuhan gula pasir tidak bisa dipenuhi oleh kapasitas produksi pabrik gula nasional yang semakin menurun, dan lebih banyak dipenuhi melalui impor.

Program diversifikasi industri gula nasional dapat dilakukan dengan cara mencari alternatif sumber sumber gula alami non tebu, salah satunya adalah gula dari aren. Program diversifikasi gula nasional yang berbasis pada gula palmae akan semakin efektif jika didukung http://ejurnal.binawakya.or.id/index.php/MBI oleh komitmen masyarakat dan kebijakan pemerintah dalam mengembangkan dan perencanaan program agroindustri gula aren yang komperehensif, terpadu dan berkelanjutan. Komoditi gula aren sudah sangat lam dikenal oleh masyarakat Indonesia dan secara nasional gula aren berpotensi menjadi salah satu komoditas subtitusi gula tebu dan berperan mengurangi ketergantungan impor gula (Burhanudin 2005).

Masyarakat Lombok Barat berada dalam kondisi lingkungan yang kaya akan veritas tanaman sangat subur, dan memiliki keterkaitan kuat dengan alam serta lingkungannya. Keterikatan masyarakat Lombok Barat dengan alam lingkungannya tampak misalnya dalam pemanfaatan alam untuk memproduksi, mendistribusi dan mengkonsumsi makanan sebagai pemenuhan kebutuhan individu, keluarga, sosial dan budayanya. Hal ini tampak pada sebuah desa, yaitu desa Kekait yang berada di wilayah Kecamatan Batu Layar, Kabupaten Lombok Barat.

Vol.14 No.1 Agustus 2019 
Desa Lembah Sari merupakan salah satu desa di Kecamatan Batu Layar, Kabupaten Lombok Barat. Kantor Kelurahan Desa Lembah Sari terletak di tengah lingkungan masyarakat yang dapat dikategorikan sebagai lingkungan yang jarang penduduk. Para perangkat desa yang terdiri atas aparat desa, pengurus PKK dan Posyandu, serta Pengurus Karang Taruna berkantor disini. Desa ini termasuk ke dalam wilayah admistratif Kecamatan Batu Layar, Kabupaten Lombok Barat,

Home idustri sebagai salah satu komponen pendukung perkembangan kepariwisataan juga berpotensi untuk dikembangkan seperti kelompok usaha gula aren yang dilakukan masyarakat Pusuk Desa Lembah Sari yang letaknya sebagian berada pada areal hutan lindung seluas $200 \mathrm{Ha}$ yang masih baik dan 631 $\mathrm{Ha}$ dengan kebun Aren/Enao seluas $80 \mathrm{Ha}$ dengan produksi nira 1.000 liter /hari dan kebun seluas 802.908 ha(sumber : Profile Desa Lembah Sari 2010) secara geografis lokasi berdekatan dengan kawasan hutan lindung Pusuk berdasarkan Perda No 9 tahun 1989 kawasan pusuk ditetapkan sebagai kawasan wisata hutan lindung dan sebagai destinasi wisata andalan di Kabupaten Lombok Barat. Pusuk Desa Lembah Sari Kecamatan Batu Layar sebuah desa pemekaran yang memiliki banyak potensi alam untuk dijadikan objek dan daya tarik wisata.

Secara teknis proses pembuatan gula aren masih dilakukan secara tradisional dan pemasaran gula aren yang memilki potensi pasar cukup bagus, sebagai bahan dasar pembuatan aneka olahan makanan dan minuman, pada sisi lain pengolahan dan pemasaran produknya masih dilakukan dengan sangat sederhana bahkan cendrung tidak memenuhi aspek hyginitas dan pendistribusiannya dilakukan dengan cara tradisional. Adapun jumlah petani gula aren yang berada di desa pusuk ini begitu banyak tersebar diareal kebun-kebun rakyat dengan jarak yang cukup jauh satu dengan yang lainnya dan pengelolaanya dilakukan secara individu dan belum berkelompok. Adapun jumlah petani gula aren di wilayah Desa Lembah Sari Kecamatan Batu Layar Kabupaten Lombok Barat seperti data dibawah ini.

Vol.14 No.1 Agustus 2019
Tabel 1. Data Petani Gula Aren di Desa Lembah Sari Kecamatan Batu Layar Kabupaten Lombok Barat

\begin{tabular}{|c|l|c|c|c|}
\hline \multirow{2}{*}{ No } & \multirow{2}{*}{ Nama Dusun } & \multicolumn{2}{|c|}{ Petani Gula Aren } & \multirow{2}{*}{ Ket } \\
\cline { 3 - 5 } & Kelompok & Perorangan & 5 \\
\hline 1 & \multicolumn{1}{|c|}{$\begin{array}{l}\text { Bengkaung } \\
\text { Lauk }\end{array}$} & - & - & \\
\hline 2 & $\begin{array}{l}\text { Bengkaung } \\
\text { Tengah }\end{array}$ & - & 6 & \\
\hline 3 & $\begin{array}{l}\text { Bengkaung } \\
\text { Daye }\end{array}$ & - & 14 & \\
\hline 4 & Bunian & - & 32 & \\
\hline 5 & Sraye & - & 7 & \\
\hline 6 & Pelolat & - & 76 & \\
\hline 7 & Bunut Boyot & - & 83 & \\
\hline 8 & Lendang Re & - & 5 & \\
\hline 9 & $\begin{array}{l}\text { Sidemen } \\
\text { Lauk }\end{array}$ & - & 93 & \\
\hline 10 & $\begin{array}{l}\text { Sidemen } \\
\text { Daye }\end{array}$ & - & 75 & \\
\hline 11 & Batu Penyu & - & 35 & \\
\hline 12 & $\begin{array}{l}\text { Kedondong } \\
\text { Atas }\end{array}$ & - & 80 & \\
\hline 13 & $\begin{array}{l}\text { Kedondong } \\
\text { Bawah }\end{array}$ & - & 49 & \\
\hline 14 & Pusuk & 2 & 57 & \\
\hline Jumlah & 2 & 612 & \\
\hline
\end{tabular}

Sumber : Profile Desa Lembah Sari

Salah satu permasalahan mendasar yang sering terjadi ditingkat pengrajin gula aren adalah masih tingginya keragaman dan tingkat penyimpangan mutu gula aren sehingga produk yang dihasilkan mempunyai mutu yang kurang sesuai dengan standar produksi. Variasi atau keragaman mutu gula aren salah satunya dipengaruhi kualitas dari standar prosedur pembuatan gula, yakni diantaranya kadar air, tekstur, warna serta komposisi di dalamnya. Gula aren yang dihasilkan perajin yang berbeda kemungkinan akan mempunyai kualitas yang berbeda dan hal ini akan mempengaruhi kualitas gula aren yang dihasilkan pula. Keragaman mutu gula tentunya mengakibatkan daya saing pasarnya rendah

Pengabdian ini bertujuan untuk mendeskripsikan keragaman kualitas gula aren dalam proses produksi dari hasil perajin. Hal ini untuk mendapatkan informasi kualitas sumber bahan baku gula aren sehingga diperoleh kualitas

http://ejurnal.binawakya.or.id/index.php/MBI 
gula aren cetak dengan kualitas terbaik (pendekatan standar SNI) Pengabdian ini diharapkan dapat memberikan informasi kualitas gula aren yang dihasilkan dari beberapa sumber bahan baku gula aren cetak, sehingga dapat menentukan sumber bahan baku terbaik untuk gula aren cetak dengan demikian variasi atau keragaman kualitas gula aren cetak dapat diminimalkan melalui penyeragaman kualitas bahan baku gula cetaknya.

\section{METODE PELAKSANAAN}

Metode kegiatan dilakukan secara bertahap melalui metode sosialisasi dalam praktik pembuatan produk kuliner dengan memunculkan wujud gula aren dalam bentuk kepingan bundar kecil seperti roti atau keeping uang logam. Kemudian setelah selesai praktik, dibagikan kuesioner untuk diisi oleh para peserta, dengan tujuan mengetahui pemanfaatan dan pemahaman akan nilai gizi serta inovasi kreasi gula aren.

Pada tahapan pelaksanaan, kegiatan awal yang dilakukan adalah sosialisasi tema mensosialisasikan tujuan kegiatan serta memetakan persiapan apa yang harus dilakukan. Langkah kedua adalah mempersiapkan bahan- bahan makanan serta hal-hal lain terkait kegiatan. Langkah terakhir adalah langkah pelaksanaan/praktik kerja.

Teknik yang digunakan dalam pengabdian ini adalah teknik observasi langsung pada pelaksaanaan praktik dengan cara mengajarkan cara pembuatan gula Areo, setelah itu hasilnya difoto untuk pendokumentasian. Teknik pemberian kuesioner pun dilakukan untuk mengetahui sejauh mana implementasinya juga peminatan peserta terhadap praktik pembuatan gula Areo ini.

\section{HASIL DAN PEMBAHASAN}

Indikator keberhasilan keberlanjutan kegiatan pengabdian dengan agenda transfer iptek tepat guna kepada mitra dapat di implementasikan dengan baik dan berkelanjutan atas permintaandan dan partisipasi mitra kelompok setelah anggota kelompok melihat dan melakukan sendiri SOP, alat cetakan, pengemasan dan pendampingan pemasaran yang http://ejurnal.binawakya.or.id/index.php/MBI dilakukan team. Tidak satupun dari kelompok mitra menghendaki kegiatan ini berhenti, sebab bagi mitra kegiatan ini sangat bermanfaat terutama bagaimana produksi yang mereka lakukan dapat dapat terus berjalan dan terus meningkat produksi dengan model pemasaran yang sudah merambah pasar modern potensial dan lebih luas

Kapasitas Produksi sebelum adanya pengabdian kapasitas produksi sangat standar dan terbatas yaitu 2 kali pagi dan sore hari dengan jumlah produksi $10 \mathrm{~kg}$ gula $/ 4$ takep per- anggota kelompok akan tetapi setelah adanya pengabdian dari team Sekolah Tinggi Pariwisata Mataram ada peningkatan yang signifikan kapasitas produksi standar yaitu 2 kali pagi dan sore hari dengan jumlah produksi $15-20 \mathrm{~kg}$ gula $/ 6$ takep per- anggota

Sebelum adanya IbM yang menjadi persoalan mitra adalah pemasaran yang hanya diambil oleh pengepul pada tingkat pasar lokal dengan harga yang relatif rendah Setelah adanya IbM masalah pemasaran dapat difasilitasi oleh kelompok yang dibentuk pasarnya tidak pada pasar lokal/tradisional melainkan sudah dapat masuk pada pasar modern seperti mini market dan outlet pada Biro perjalanan wisata

Peran serta mitra dalam kegiatan pelatihan maupun penyuluhan sangat aktif dalam berpartisifasi dalam rangka pengembangan produksi dengan memperkenalkan teknologi produksi yang efesien, pengemasan yang menarik, pemasaran maupun penyuluhan dalam rangka pemuliaan tanaman untuk mendapatkan hasil yang lebih produktif, kesediaan petani dengan sukarela mau menyediakan dana ekstra untuk kepentingan produksi seperti pembelian bahan baku nira kepada petani lain, pembelian bahan bakar dalam rangka memenuhi target produksi gula aren sesuai kapasitas produsi yang diharapkan, pembelian bahan pengemasan alternatif maupun membangun koordinasi dengan sesama anggota dalam satu wilayah kerja.

Dalam rangka proses produksi penyedian bahan yang diperlukan menjadi tanggung jawab mitra, selama proses pengabdian dilapangan team tidak pernah kesulitan dalam memperloh bahan

Vol.14 No.1 Agustus 2019

\section{Open Journal Systems}


baku yang diperlukan baik dalam proses produksi, pengemasan, pemasaran maupun proses yang lain berjalan lancer, Kegiatan dilapangan memang tidak bisa diprediksi dengan pasti telebih lagi berhubungan dengan masyarakat yang aktivitas kesehariannya sangat kental dengan aktivitas narep, mengolah yang hampir suntuk habis waktunya seharian diladang enau, maka dalam menetapkan teknis pelaksanaan sangat dipengaruhi oleh kondisi internal petani, sehingga waktu dilapangan untuk bisa ketemu dan bertatap muka dengan para petani diperlukan kesabaran dan rela seharian menunggu waktu yang benar-benar lowong supaya jangan menggangu aktivitas petani, secara teknis pleksibilitas program sangat diperlukan

Mengubah strategi pendekatan di lapangan merupakan strategi yang jitu agar mendapatkan hasil sesuai dengan target program tanpa mengurangi kualitas dan kuantitas kegiatan yang telah direncanakan, karena kondisi lapangan sangat berbeda dengan harapan program yang telah disusun dengan baik dan sistematis, pendekatan humanis dan persuasif menjadi pilihan menghadapai kondisi riil petani dilapangan, Objek Kegiatan yang dilakukan masih berfokus pada kegiatan penyuluhan tanaman, proses produksi dengan sentuhan teknologi tepat guna yang efesien dan efektif, model pengemasan yang hygienis, perluasan pemasaran mencapai pasar yang lebih luas dan modern serta menjadikan proses ini sebagai salah satu atraksi wisata.

Gambar 1. Pemanenan Aren

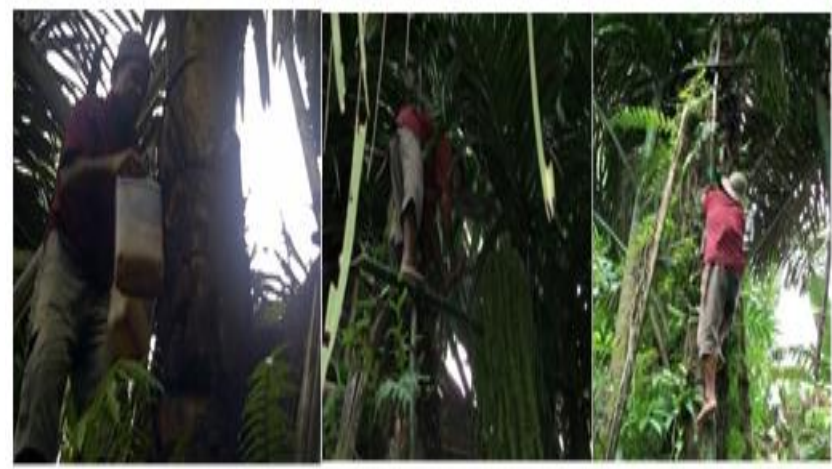

Vol.14 No.1 Agustus 2019
Gambar 2. Proses Pencetakan Gula Aren sampai pengemasan

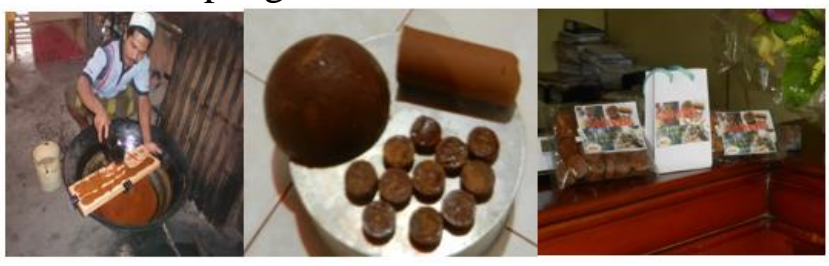

Gambar 3. Proses Pembuatan Pengolahan Nira Menjadi Gula Aren

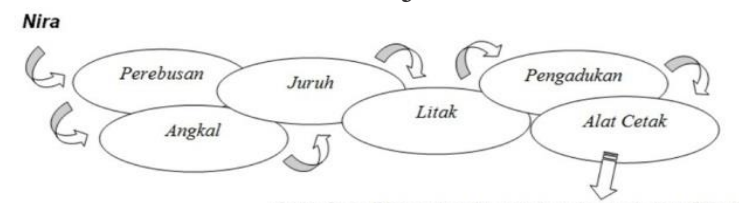

Gula Aren Dituangkan ke cetakan (acuan) dan didinginkan.

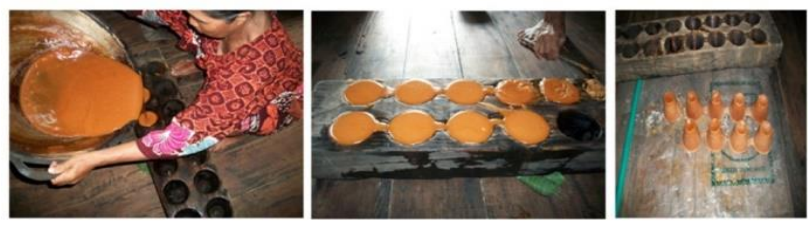

Gambar4. Alur Proses Pemasaran gula Aren Setelah selesai melakukan semua tahapan proses pembuatan gula Aren maka dilanjutkan dengan proses penjualan. Adapun alur penjualan gula Aren dapat dilihat dalam bagan alur

Gambar 4. Alur Pemasaran Gula Aren

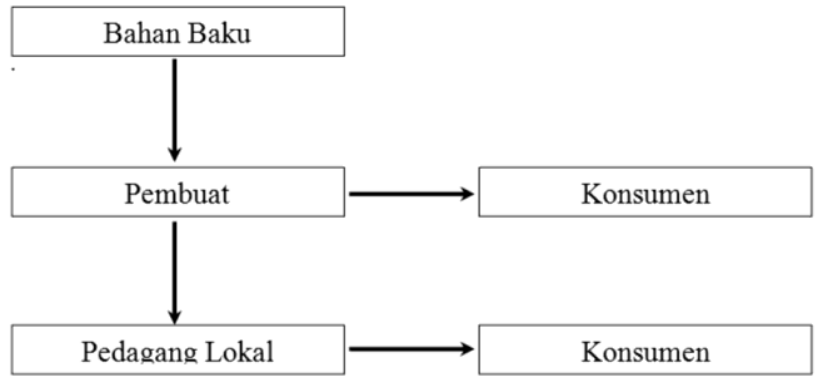

Pembuat gula Aren ini lebih sering memasarkan gula Arennya kepada pemesanan dari pihak- pihak tertentu. Jika tidak terdapat pesanan, maka mereka menjualnya kepada pedagang lokal yang mengambilnya setiap hari. Harga jual gula Aren berkisar Rp. 25000,- sd. Rp. 30.000,- per kilogramnya. Dengan adanya aktivitas produksi yang meningkat membuka peluang bagi para kelompok tani yang ada untuk membangun

http://ejurnal.binawakya.or.id/index.php/MBI 
wadah wira usaha baru dari produk gula aren seperti yang dilakukan kelompok usaha tani di Desa Lembah Sari dengan menggunakan bahan dasar yang bersumber dari pohon enao seperti Kolang kaling dengan turunannya menjadi kerupuk, dodol, es kolang kaling dan sejenisnya. Sagu yang berasal dari batang pohonnya yang sudah tua menjadi berbagai jenis jajanan sagu, serta cindra mata yang terbuat dari ruyung atau klit luar batang enao untuk alat pertanian maupun alat runmag tangga.

\section{PENUTUP}

Gula merupakan salah satu komoditi penting dan strategis bagi masyarakat, program diversifikasi industri gula nasional dapat dilakukan dengan cara mencari alternatif sumber sumber gula alami non tebu, salah satunya adalah gula dari aren.

Salah satu pendukung home idustry yang berpotensi untuk dikembangkan dalam industry pariwisata adalah pemberdayaan petani aren yang dikemas dalam satu paket produk ekowisata yang dilakukan masyarakat Pusuk Desa Lembah Sari.

Kapasitas Produksi menunjukkan adanya peningkatan yang sangat signifikan dari kelompok petani gula aren dalam memproduksi gula dengan berbagai model dan bentuk dengan kapasitas produksi satu hari 2 kali pagi dan sore hari dengan jumlah produksi mencapai $15-20 \mathrm{~kg}$ gula /6 takep per- hari dan per- anggota.

Dengan pola produksi dan yang meningkat sangat memungkinkan adanya pemasaran produk yang baik dengan pasar sasran tidak saja konsumen lokal tapi juga konsumen yang lebih luas dan menjakau pasar modern sperti beberapa swalayan yang ada di kota Mataram.

\section{DAFTAR PUSTAKA}

[1] Anoraga, P. 1993. Produktivitas Kerja dan Faktor- Faktor yang mempengaruhinya. ProNo.XXX/Tahun 4, Jakarta.

[2] Dinas Kehutanan Provinsi Jawa Tengah. http:// lumbungmedia.com/. Budidaya dan Potensi Tanaman Aren. Diakses Tanggal 2November 2013

http://ejurnal.binawakya.or.id/index.php/MBI
[3] Fajariyah, Maya. 2010. Produktivitas Pembuatan Gula Aren (Arenga Pinnata Merr) dan Kontribusinya Terhadap

Pendapatan Masyarakat di Desa Guntung Kecamatan Haruyan Kabupaten Hulu Sungai Tengah. Skripsi. Fakultas Kehutanan Universitas Lambung Mangkurat, Banjarbaru.

[4] Martaniah,S. M; B. S. Rasimin; A. W. Pratiknya; A.W. Sutomo; dan F. Himam. 1990. Hubungan Antara Terpenuhinya Kebutuhan Fisik Minimal dan Produktivitas kerja di Provinsi Jawa dan Sumatra Utara. Laporan penelitian. Yogyakarta: Fakultas Psikologi UGM.

[5] Moelyono, M. S. E. 1993. Penerapan Produktivitas Dalam Organisasi. Bumi Aksara, Jakarta.

[6] Nusi. 2007. Kontribusi Usaha Kerajinan Rotan Terhadap Pendapatan Rumah Tangga Petani Di Kabupaten Tapin Kalimantan Selatan. Tesis. Program Pasca Sarjana Program Studi Ekonomi Pertanian Universitas Lambung Mangkurat, Banjarbaru. Tidak Dipublikasikan.

[7] Profil DesaKekait Kecamatan Batulayar Kabupaten Lombok Barat, 2018

[8] Pudjawati Sajogyo. 2002. Sosiologi Pedesaan.Gajah Mada University Press, Yogyakarta.

[9] Safari, A. 1995. Teknik Membuat Gula Aren. Karya Anda, Jakarta.

[10] Sarwono, J., 2006. Metode Penelitian Kuantitatif \& Kualitatif. Graha Ilmu, Yogyakarta.

[11] Slamet, S. 1993. Bertanam Aren. Penebar Swadaya.Jakarta.

[12] Sunanto, Hatta, 1993. Aren Budidaya dan Multigunanya. Kanisius, Yogyakarta

[13] Rosidah R Radam \& Arfa Agustina Rezekiah, 2015, Pengolahan Gula Aren (Arrenga Pinnata Merr) Di Desa Banua Hanyar Kabupaten Hulu Sungai Tengah, Jurnal Hutan Tropis Volume 3 No. 3

[14] Susi,2013, Pengaruh Keragaman Gula Aren Cetak terhadap Kualitas Gula Aren Kristal (Palm Sugar)Produksi Agro Industrei Kecil,

Vol.14 No.1 Agustus 2019 
ZIRAA'AH, Volume 36 Nomor 1, Pebruari

2013 Halaman 1-11 